\title{
PAC MPABE
}

УДК 929 Bogišić

Др Жељко Фајфрић адвокат у Шиду

\section{НЕОСТВАРЕНА ЗАДУЖБИНА ВАЛТАЗАРА БОГИШИЋА*}

„Ја нећу да мој једини син буде службовати кас чиновник по свијету дочим може господовати код куће, као слободан човјек, тек нагледајући кућно имање које долази од старијих. Тако силовити и свирјепи карактер, као мој син, био би несретан у сваком зависном положају. А уз то, ко ће продужити, и у будуће, опстанак и глас куће, ко Һе отца одмјенити у старијим годинама, ако једини мушки насљедник у свијет оде", ${ }_{1}$ говорио је Влахо Богишић о будућем животном путу свога сина Валтазара. И заиста, Валтазар Богишић, будући научник светског гласа, се све до смрти свога оца тек овлаш бавио хуманистичким наукама. Са непуних 13 година завршио је у Цавтату наутички курс (што су други чинили са 18 година) и чинило се да hе наставити традицију познате шавтатске породице Богишић, односно, бавити се поморством и трговином.

Безбрижне године учења у Цавтату нагло су прекинуте очевом смрти (1856. године), а чини се да је тутор одреБен Валтазару и његовој сестри био све само не заштитник њихових имања. Ипак, након наступпања пунолетства Валтазар је успео да се избоори за наследство, па чак и да начини неколико добрих послова. О тим првим годинама сам казује: „Ријеч је: у старој кући, много паучине! Са тим паучинама за цигле двије године своје үправе, тј. своје велике непрестане борбе, он с неколико умно зачетих и сретно изведених економских операшија, упркос свијем противнштинама исплати дугове, удаде сестру и намири њезин дио, осигура средства за своје предположене више науке и без ичигових стипендија а поврх свега тога,

* Рад примъен: 29. V 1998.

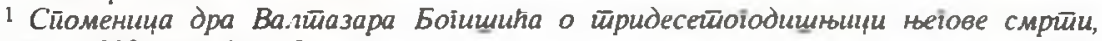
Дуббровник 1938, стр. 41-42. 
уреди и удеси уопће имовне прилике тако, како су позније постепено све кућне некретнине, отуБене диобама, опет његове постале, а и иначе се имовински одношаји доведоше у доста цватуће стање."2

Од тога момента и он је био слободан да се почне бавити оним што га највише интересује. Тако је кренуо његов пут учења - од гимназије у Венецији преко универзитетских студија у Бечу, Берлину, Гисену, Минхену, Хајделбергу. Након тога дошла су многобројна путовања кроз Француску, Белгију, Италију, кроз скоро све словенске земъе. У међувремену је стекао докторат историјских наука, онда докторат правних наука и коначно при позиву за професора словенских права у Одеси, изабран је и почашћен као doctor honoris causa Универзитета у Одеси. ${ }^{3}$

Често је боравио у Аустрији, али и поред свега био је „одушевљени и велики родољуб,, само се љуто бојао германске најезде”. Интересантна су његова размишљања о Србима и Хрватима: „О двојству меБу Сробима и Хрватима чути није хтео ни речи дати! За себе је, истина, увек говорио да је Срб́ин и српскога рода и кољена; али је и говорио да је Хрват исто што и Сро́ин; један народ са два имена. Жалио је што има разних имена и разних вера у нашем народу. За себ́ је рекао да је рођен католик и да Һе као такав и умрети, али да је православна црква једина народна црква, и да њу стога треб́а чувати."4

Валтазар Богишић је обављао изненаБујуће различит број занимања - од библиотекара Бечке царске библиотеке до инспектора школа у Војној граници, професора универзитета у Русији, законодавца и министра правде у Црној Гори. Уз све то био је и писац многих научних расправа и већих дела. ${ }^{5}$ Оно што је за њега било посебно карактеристично, и што скоро увек некако измиче, јесте да су све то били положаји који су му доносили добру прилику да своје, већ ионако велико породично богатство, увећа до огромних размера. Није познато да је иједан научник XIX века на Словенском југу био од њега имућнији. Заправо, Богишић је био свестан својих квалитета и знао их је уновчити.

\section{2 lbid., crp. 72.}

3 Како се нсһу упуштати у детаљнију разрату Богишиһсве биографије, то уту-

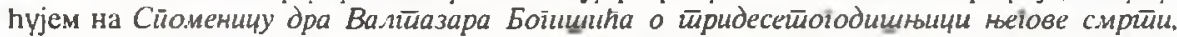
Дубровник 1938, али како је та књига данас тешко приступачна то упуһујем на књигу из серије „Класици Југословенског права” књига 2, Ваптазар Богишиһ: Нзаорана дела и Ойцйи имоеєнски Законик за Црну Гору, Београд 1986, где се на странама 5-40. даје довољно података у Богишићу и његовом делу.

4 Из писма блиског Богишићевог пријатеља Ивана Павловиһа. Писмо је писано након Богишиһсвс смрти - 11. децемб́ра 1908. годннс. Писмо се налази у Архиву Богишићевог музеја у Шавтату, сигн. 65.

5 Бибблиографија објављена у 3. књизи „Класици Југословснског права" - Ваттазар Богишиһ: Изабрана дела и Ойщйи имовински законик за Црну Гору, Београд 1986, стр. $501-507$. 
Великих трошкова он никада није имао, а умео је да своје захтеве око висине хонорара истерује до границе која је могла да доведе и до конфликта. Остале су познате његове полемике око, по њему премало исплаћених хонорара са установама таквог ауторитета каквог су Југославенска академија, Српско учено друштво у Београду, са Рачким у Загребу, са Стојаном Новаковићем у Београду. Чак, и његов најпознатији научни рад - на Црногорском законику - није могао проћи без тога. Неколико година након завршетка Законика, који је радио по наредби руског цара и богато плаћеној командировки, он се натезао са царском владом око додатног исплаћивања посеб̆н награде. А она је била стварно царска. Све трошкове око израде Законика, а они су били заиста велики, чак 160.000 руб́аља, ишли су на терет руске владе и она их је уредно платила. А када је дошла на ред Богишићева награда настали су проблеми. Валтазар је тражио 40.000 рубо́ља, али је на крају морао да се задовољи са 20.000.

Био је веома штедљив, није се женио, без деце, а једини трошкови су му били многобројна путовања, колекционирање ретких књига, графичке вредности разних мајстора, нумизматички раритети. Таквим пословима могу да се баве људи са огромним знањем и што је важније - са префињеним укусом.

Ипак, његова преписка одаје изузетно шкртог и строгог човека чија обрачунавања многобројних поруџо̆ина прелазе у несимпатичан тврдичлук. ${ }^{\circ}$ Чак ни његов одлазак у пензију није могао да буде лишен натезања око висине пензије. Руска влада му је понудила уобичајену пензију коју је он одбио, а онда је добио пензију какву је могао мало ко да очекује - пуну плату редовног професора Одеског универзитета (око 3.000 руббаља). Меьутим, он је такву пензију сматрао увредом, додуше, није је одбио, али се одмах преселио у Париз и никада више није посетио Русију (пензију је и даље уредно примао).

Иако је био поштован као изузетан научник, Валтазар Богишић није уживао углед посебно трпељивог човека, а све зарад својих сталних настојања да заради што више. „Управо ради његових захтева новчане награде тако је раскрстио с Русијом, да није нигда више хтео да из Париза пође тамо", описује Јагић сукоб Богишића са царском владом. ${ }^{7}$ У Богишићевом архиву у Цавтату постоји неколико писама у којима се доста спомињу сукоби Богишићеви око исплата хонорара за израду Законика. ${ }^{.}$Таквих материјала има и на

6 А таквих примера је заиста много. Погледати у В. Јагиh: Сйомени иојеіа лсивойа, Београд 1934, Н. Мартиновић: Валйазар Бойtиић и исйорија кодификације црноїорскоі имовинскоі йрава, Цетиње 1958, В. Новак: Валйазар Боіищић̆ и Франо Рачки, Прейиска (1866-1893); Збоорник за историју, језик и књижевност српског народа САН XXV, Београд 1960).

7 В. Јагић: Сйомени мојеіа жсивойа. Београд 1934, стр. 67.

8 XXIII кутија под бројем 4. под насловом „Односи с Русијом. Спор са властима о награди за рад на Законику". 
Цетињу у Државном музеју, ${ }^{9}$ док у Историјском институту у мемоарима војводе Симе Поповића се Валтазар Богишић описује као среброљубац. Поповић наводи такође да ни књазу Николи није био Богишић превише омиљен због тога што су му „миле паре”.

Имао је доста готовине коју је држао на два рачуна - у Бечу и Паризу, а осим тога поседовао је и неколико бродова и мноштво хартија од вредности у ко зна колико предузећа. И сам је био свестан свога огромног богатства, па се већ̆ пред крај живота почео размишљати како да га подели. У томе није успео јер га је смрт задесила изненадно (1908. године). Интересантно да је пред смрт размишљао да се стално настани у Београду: „Размишљао је, у последње време одселити се из Париза. У Аустро-Угарску нипошто није хтео стално се враћати. Највише је се устављао на помисли населити се у Београду; само су му непријатне биле унутрашње политичке зађевиде; те је се бојао да би му то онемилило бављење у Србији."”

По неким наводима" Богишић је имао намеру да оснује у Београду „Задужбину В. Богишића” којом би управљао Одбор од седам људи. Задужбина би била веома богата јер је у њу требала ући целокупна Богишићева имовина. Капитал би се употребљавао тако што би се помагала тројица научника (једног православног, једног католика и једног мухамедовца) да се у иностранству усаврше у својим студијама. Сви би они требали да раде на једној од грана етнографије јужнословенске (историја, право, умотворине, филологија, итд.). „То би помагање могло распрострти се на исте људе за неколико година, све док Одбор нађе да је оправдано; а помоћ би износила по 300 франака месечно свакоме. Одбор би прописао правила о томе, и старао се како ће контролисати рад и успех тих питомаца. Свакојако, не може се примити ниједан, који не би већ показао наклоност и успех у том послу. Ти „питомци Богишићеви” обавезни би били, за све време свог живота и деловања на науци, бар по један свој рад годишње, без хонорара за њ, уступити Задужбини за Годишњи помен."

Задужбина би такође̨ издавала посебни Годищњи йомен В. Боіищић, заправо нека врста Зборника у којем би били сабрани одабрани списи из етнографије јужнословенске.

Осим овога Задужбина би издала све заостале рукописе Валтазара Богишића, давала би свечани помен завештаоцу (Богишићу) у цркви и на гробу сваке године, израдила надгробни споменик и бринула се о њему.

9 Објавио их Д. Вуксан 1936. године под називом Зайиси.

10 Из писма блиског Богишићевог пријатеља Ивана Павловића. Писмо је писано након Богишићеве смрти - 11. децеморра 1908. године. Писмо се налази у Архиву Богишићевог музеја у Цавтату, сигн. 65.

II Блиски Богишићев пријатељ Иван Павловић у писму од 11. децембра 1908. године упознаје Богишићеву сестру са плановима које је имао њен брат. Писмо се налази у Архиву Богишићевог музеја у Цавтату, сигн. 65. 
Све су ово били планови који нису могли бити реализовани будући да је Валтазар Богишић умро без тестамента тако да је његову целокупну имовину наследила његова сестра. Како је умро у Ријеци то су Богишићеви посмртни остаци пренети у Цавтат где су и сахрањени. Споменик је подигла цавтатска општина, а израдио га је вајар са Корчуле - Петар Палавичини. И споменик је интересантан, исто онако како је био и Богишићев живот. На једном постољу он посматра негде у даљину, а како каже сам вајар - у вечиту будућност народа коме је он научно служио и у великом свету га достојно представљао. Оно што је свакако највредније јесте Богишићева богата библиотека, архив и разне збирке, које су из Париза пренете у Цавтат и смештене у бившу кнежевску палату. 